\title{
Toxoplasma gondii-skeletal muscle cells interaction increases lipid droplet biogenesis and positively modulates the production of IL-12, IFN-g and $\mathrm{PGE}_{2}$
}

Alessandra F Gomes ${ }^{1}$, Kelly G Magalhães², Renata M Rodrigues', Laís de Carvalho³, Raphael Molinaro", Patrícia T Bozza ${ }^{4}$ and Helene S Barbosa ${ }^{*^{*}}$

\begin{abstract}
Background: The interest in the mechanisms involved in Toxoplasma gondii lipid acquisition has steadily increased during the past few decades, but it remains not completely understood. Here, we investigated the biogenesis and the fate of lipid droplets (LD) of skeletal muscle cells (SkMC) during their interaction with T. gondii by confocal and electron microscopy. We also evaluated whether infected SkMC modulates the production of prostaglandin $E_{2}$ $\left(\mathrm{PGE}_{2}\right)$, cytokines interleukin-12 (IL-12) and interferon-gamma (INF-g), and also the cyclooxygenase-2 (COX-2) gene induction.

Methods: Primary culture of skeletal muscle cells were infected with tachyzoites of $T$. gondii and analysed by confocal microscopy for observation of LD. Ultrastructural cytochemistry was also used for lipid and sarcoplasmatic reticulum (SR) detection. Dosage of cytokines (IL-12 and INF-g) by ELISA technique and enzyme-linked immunoassay (EIA) for $\mathrm{PGE}_{2}$ measurement were employed. The COX-2 gene expression analysis was performed by real time reverse transcriptase polymerase chain reaction (qRT-PCR).

Results: We demonstrated that T. gondii infection of SkMC leads to increase in LD number and area in a time course dependent manner. Moreover, the ultrastructural analysis demonstrated that SR and LD are in direct contact with parasitophorous vacuole membrane (PVM), within the vacuolar matrix, around it and interacting directly with the membrane of parasite, indicating that LD are recruited and deliver their content inside the parasitophorous vacuole (PV) in T. gondii-infected SkMC. We also observed a positive modulation of the production of IL-12 and IFN-g, increase of COX-2 mRNA levels in the first hour of T. gondii-SkMC interaction and an increase of prostaglandin $E_{2}\left(P_{G} E_{2}\right)$ synthesis from $6 \mathrm{~h}$ up to $48 \mathrm{~h}$ of infection.

Conclusions: Taken together, the close association between SR and LD with PV could represent a source of lipids as well as other nutrients for the parasite survival, and together with the increased levels of IL-12, INF-g and inflammatory indicators $\mathrm{PGE}_{2}$ and COX-2 might contribute to the establishment and maintenance of chronic phase of the T. gondii infection in muscle cell.
\end{abstract}

Keywords: Toxoplasma gondii, Lipid droplets, Skeletal muscle cells, Prostaglandin-E, Cytokines

\footnotetext{
* Correspondence: helene@ioc.fiocruz.br

'Laboratório de Biologia Estrutural, Instituto Oswaldo Cruz, Fundação

Oswaldo Cruz, Rio de Janeiro, Brazil

Full list of author information is available at the end of the article
} 


\section{Background}

T. gondii is an obligatory intracellular protozoan parasite that resides within a PV, which fails to fuse with host organelles from the endocytic pathway [1,2]. This condition potentially deprives parasites of a large source of nutrients from the host endocytic and exocytic system [3]. It is known that T. gondii alters the metabolism of the host cell during the invasion and replication using host-derived nutrients in their own metabolic pathways [4], and that T. gondii does not synthesize its own cholesterol but relies mostly on host-derived lipids for their survival [5]. The mechanisms involved in T. gondii lipid acquisition are a matter of interest and are still not completely understood. Some studies show the involvement of organelles such as mitochondria and mainly the endoplasmic reticulum (ER) of host cell as suppliers of lipids, thus contributing to the increased area of vacuoles membrane during the development of the parasite [6]. In addition, T. gondii infection leads to increased receptormediated cholesterol endocytosis by the low-density lipoprotein (LDL) pathway [1,7].

Recent studies have proposed a dynamic role for LD in the host response to intracellular pathogens. Pathogeninduced increased LD formation has been described in bacterial, viral, fungal and parasitic infections where a role for this organelle in intracellular survival and replication of pathogens has been proposed [8,9]. Of note, a close association and/or the presence of host-cell LD in pathogencontaining vesicles has been detected in cells infected with Mycobacterium tuberculosis [10,11], Mycobacterium bovis BCG [12,13], Mycobacterium leprae [14], Chlamydia [15], as well as with protozoan parasites Plasmodium falciparum [16] and Trypanosoma cruzi $[17,18]$, suggesting a role for LD in lipid trafficking during infection.

Structurally, the LD consists of a nucleus of cholesteryl esters and triglycerides surrounded by a single monolayer of phospholipids [19]. The regulated formation of lipid droplets, their protein and lipid content, and their association with other intracellular organelles have established LD as specialized, inducible cytoplasmic domains that function not only in lipid storage but as organelles with roles in cell signaling and activation, regulation of lipid metabolism, membrane trafficking and control of the synthesis and secretion of inflammatory mediators [20,21]. Accordingly, increase of LD numbers produced during infection is related to the generation of eicosanoids, where LDs have been shown as sites of compartmentalization of eicosanoid-forming enzymes and domains involved in the mechanisms of enhanced eicosanoid production during inflammatory and infectious conditions $[12,17,22]$ such as prostaglandin $\mathrm{E}_{2}\left(\mathrm{PGE}_{2}\right)$, a product of cyclooxygenase-2 (COX-2) gene induction [23]. However, the LD formation in $T$. gondii and the transference of the host cell lipids to the parasite across the parasitophorous vacuole membrane
(PVM) as well as the participation of ER for the maintenance of the intravacuolar parasites were not fully addressed and remain uncertain.

The LDs are also described as sites of storage and synthesis of cytokines. During the past few years SkMC was identified and characterized as a cytokine-producing cell, capable of producing muscle derived cytokines, the myokines, which may participate during infection by intracellular-muscle pathogens such as T. gondii [24]. It is known that some cytokines such as interleukin-12 (IL-12), and particularly interferon gamma (IFN-g) are directly involved in cytogenesis [3], the survival rate of T. gondii in SkMC [25] and also the integrity of muscle tissue injury [26]. So we studied the formation of LD muscle cells induced by infection with $T$. gondii and investigated if this infection may modulate the production of IL-12 and IFN-g in this cell type. Besides, some researchers have discussed the importance of the host cell type as a determinant for tachyzoite to bradyzoite conversion $[27,28]$. It has been demonstrated that primary skeletal muscle cells trigger spontaneous $T$. gondii tachyzoite-to-bradyzoite conversion at higher rates than fibroblasts present in these cultures [29,30]. In the past, little attention had been given to the use of SkMC as potential host cells during the study of the toxoplasmosis, despite its well-known participation during the chronic phase of the disease [31], and its role in the route of parasite transmission via consumption of raw or undercooked meat containing Toxoplasma [32]. In the few last years, our group has been working with primary cultures of SkMC as an experimental model for the study of toxoplasmosis in vitro, which opens new perspectives in this field [2,27,29,30,33-36]. Since, T. gondii diverts a large variety of lipid precursors from host cytoplasm and efficiently manufactures them into complex lipids to its own benefit $[4,37,38]$, we hypothesized a role for LD biogenesis during $T$. gondii infection.

In this study, we have investigated the role of LD biogenesis and their interaction with PV, the modulation of IL-12 and IFN-g secretion as well as COX-2 gene expression and $\mathrm{PGE}_{2}$ synthesis, during T. gondii-SkMC infection in order to better understand the survival mechanisms of Toxoplasma in muscle cells.

\section{Methods}

All procedures were carried out in accordance with the guidelines established by the Colégio Brasileiro de Experimentação Animal (COBEA), by Fundação Oswaldo Cruz Fiocruz Committee of Ethics for the Use of Animals (license CEUA LW 10/10) and by the Guidelines on the Care and Use of Animals for Experimental Purposes and Infectious Agents (NACLAR). 


\section{Primary culture of skeletal muscle cells}

Skeletal muscle cell primary cultures were obtained from disaggregated thigh muscles of 18-day-old Swiss-Webster albino mouse embryos. The tissues were minced and incubated for $7 \mathrm{~min}$ with $0.05 \%$ trypsin and $0.01 \%$ versene diluted in phosphate-buffered saline pH 7.2 (PBS). After 5-7 dissociation cycles, the enzymatic digestion was interrupted by adding $10 \%$ fetal bovine serum at $4^{\circ} \mathrm{C}$, the suspension was centrifuged at $650 \mathrm{~g}$ for $7 \mathrm{~min}$, resuspended in Dulbecco's modified Eagle medium (DMEM) supplemented with $10 \%$ horse serum, $5 \%$ fetal bovine serum, $2 \%$ chick embryo extract, $1 \mathrm{mM}$ L-glutamine, 1,000 U/ml penicillin, $50 \mu \mathrm{g} / \mathrm{ml}$ streptomycin and then incubated for $30 \mathrm{~min}$ at $37^{\circ} \mathrm{C}$ in a $5 \% \mathrm{CO}_{2}$ atmosphere. After incubation, the culture flask was gently shaken to release the nonattached cells and the supernatant enriched with myoblasts was seeded in $0.02 \%$ gelatin-treated 24-well culture plates (for fluorescent assays) or in $35 \mathrm{~mm}$-culture plates (for electron microscopy studies), respectively. The cultures were maintained at $37^{\circ} \mathrm{C}$ up to 3-5 days to obtain the muscle fibers and the fresh medium was added every two days. The main characteristics of the cells during myogenesis are: The myoblasts, which are the mononucleated precursor cells of muscle fibers, culture divides two to three times and then begins to aggregate and fuse into postmitotic multinucleated muscle fibers. Moreover, fibroblast phenotype in culture is as follows: the spread exhibited outwards, stellate morphology of fibroblast - like cells and freshly isolated cells demonstrates that the fibroblasts were larger than the myoblasts [36].

\section{Parasites}

Tachyzoites of $T$. gondii, $\mathrm{RH}$ strain, were maintained in Swiss mice by serial intraperitoneal inoculation of $10^{5}$ parasites after 48-72 $\mathrm{h}$ inoculation. The parasites were harvested in PBS and centrifuged (200 g for 7-10 min) at room temperature in order to discard blood cells and cellular debris. The supernatant was collected and then centrifuged again at $1000 \mathrm{~g}$ for $10 \mathrm{~min}$. The final pellet was resuspended in DMEM and used in the parasitehost cell interaction assays.

\section{Lipid droplet staining and counting}

Muscle cells infected or not with $T$. gondii (parasite: host cell approximate ratio of 5:1) after 6, 24 and $48 \mathrm{~h}$ were fixed in $3.7 \%$ formaldehyde in HBSS ( $\mathrm{pH} 7.4$ ) and stained with osmium tetroxide, or BODIPY. For the osmium staining, the slides were rinsed in $0.1 \mathrm{M}$ cacodylate buffer, incubated with $1.5 \%$ osmium tetroxide (OsO4) for $30 \mathrm{~min}$, rinsed in $\mathrm{H}_{2} \mathrm{O}$, immersed in $1.0 \%$ thiocarbohydrazide for $5 \mathrm{~min}$, rinsed in $0.1 \mathrm{M}$ cacodylate buffer, reincubated in $1.5 \% \mathrm{OsO} 4$ for $3 \mathrm{~min}$, rinsed in distilled water, and then dried for further analysis. The morphology of fixed cells was observed, and lipid bodies were enumerated by light microscopy with $\times 100$ objective lens in 50 consecutive cells in each slide. The quantitative analysis was based on 3 independent experiments performed in duplicate with at least 200 cells in each coverslip. The person responsible for counting was blinded to the codes for each slide. Slides were alternatively stained with BODIPY, evidencing the accumulation of neutral lipids in lipid droplets. For the BODIPY staining, the slides were fixed in $3.7 \%$ formaldehyde for $10 \mathrm{~min}$, washed and incubated for $15 \mathrm{~min}$ with the vital stain BODIPY-493/503 (4,4-difluoro-1,3,5,7, 8-pentamethyl-4-bora-3a,4a-diaza-s-indacene) or Nile red diluted in PBS, in the proportion of 1:200 and 1:1000 $(\mathrm{v} / \mathrm{v})$, respectively. The cultures stained by BODIPY were washed in PBS, incubated for $10 \mathrm{~min}$ with $1 \mu \mathrm{M}$ of ToPRO_3 iodide-642/661 in PBS to enable the visualization of the nuclei of cells, followed by $4 \mu \mathrm{g} / \mathrm{mL}$ phalloidinTRITC (binds to the actin cytoskeleton) for $1 \mathrm{~h}$ at $37^{\circ} \mathrm{C}$ for better visualization of SkMC. The coverslips were mounted over the sections with 2.5\% 1.4-diazabicyclo(2.2.2)-octane (DABCO). The samples were examined using a Zeiss photomicroscope equipped with epifluorescence and a confocal laser scanning microscope Fluoview 3.2 Olympus, with objective lens of $63 \times$ and of 100× (Farmanguinhos/Fiocruz).

The measurement of the area of lipid droplets was done using the BODIPY fluorescent images, obtained with an objective lens of $63 \times$ (at least four fields per slide). The images were scanned and analyzed with $2 \mathrm{D}$ image software (LSM Image Browser 5). The spots were determined by automatic detection, and the total area of fluorescent lipid bodies were quantified and compared to the lipid bodies of uninfected cells.

\section{Transmission electron microscopy}

SkMC were allowed to interact for 4 to $48 \mathrm{~h}$ at $37^{\circ} \mathrm{C}$ with tachyzoites of $T$. gondii (parasite: host cell approximate ratio of 5:1). After washing in PBS, the uninfected and $T$. gondii-infected SkMC were immediately fixed for $30 \mathrm{~min}$ at $4^{\circ} \mathrm{C}$ in $2.5 \%$ glutaraldehyde solution (GA) in $0.1 \mathrm{M} \mathrm{Na}$ cacodylate buffer containing $3.5 \%$ sucrose and $2.5 \mathrm{mM} \mathrm{Ca}^{+2}, \mathrm{pH} 7.2$. The cells were then washed in the same buffer and post-fixed for $30 \mathrm{~min}$ at $4^{\circ} \mathrm{C}$ in $1 \%$ $\mathrm{OsO}_{4}$ in cacodylate buffer. After fixation, the cells were scraped gently from the plastic dish and centrifuged for $5 \mathrm{~min}$ at $10,000 \mathrm{~g}$, dehydrated in acetone and embedded in PolyBed 812 resin. Thin sections were contrasted in uranyl acetate and lead citrate and examined in a Zeiss EM10C transmission electron microscope at the Electron Microscopy Platform of Instituto Oswaldo Cruz.

\section{Ultrastructural cytochemistry for lipid detection}

SkMC infected with T. gondii for 4 and $24 \mathrm{~h}$ were washed in PBS and fixed for $1 \mathrm{~h}$ at room temperature with $2.5 \% \mathrm{GA}$ in $0.1 \mathrm{M} \mathrm{Na}$ cacodylate buffer with the 
addition 3.5\% sucrose, pH 7.2. The cultures were washed in the same buffer for $10 \mathrm{~min}$ and immediately incubated for another $10 \mathrm{~min}$ in $0.1 \mathrm{M}$ of imidazole buffer $\left(\mathrm{CH}_{3} \mathrm{H}_{4} \mathrm{~N}_{2}\right), \mathrm{pH} 7.5$ [39]. After washing, the cultures were post-fixed for $30 \mathrm{~min}$ at room temperature in $2 \%$ $\mathrm{OsO}_{4}$ diluted in imidazole buffer, $\mathrm{pH}$ 7.5, in the dark. After incubation, the cells were washed twice for $10 \mathrm{~min}$ in imidazole buffer and then processed for transmission electron microscopy. The ultrathin sections were contrasted with lead citrate for $1 \mathrm{~min}$ and examined in a Zeiss EM10C transmission electron microscope.

\section{Ultrastructural cytochemistry for sarcoplasmatic reticulum (SR) detection}

After 4 and $24 \mathrm{~h}$ of interaction with T. gondii, the infected SkMC cultures were washed in PBS and fixed for $30 \mathrm{~min}$ at room temperature in $2.5 \% \mathrm{GA}$ in $0.1 \mathrm{M}$ cacodylate $(\mathrm{pH}$ 7.2). The cells were washed twice for $15 \mathrm{~min}$ in the same buffer and washed again twice for $10 \mathrm{~min}$ in $1 \%$ potassium iodide (KI) diluted in distilled water. The cultures were then incubated for $48 \mathrm{~h}$ (in the dark) at room temperature in $1 \% \mathrm{OsO} 4$ and $1 \% \mathrm{KI}$, washed for $10 \mathrm{~min}$ in $\mathrm{KI}$ solution diluted in distilled water [40] and finally processed as routine for transmission electron microscopy. The ultrathin unstained sections were examined in a Zeiss EM10C transmission electron microscope.

\section{Cytokine measurement}

Cell-free supernatants from muscle cell culture infected by T. gondii per 6, 24 and $48 \mathrm{~h}$ and controls were harvested and used for IL-12 and INF-g cytokine level measurements by ELISA, following the manufacturer's recommendations for each kit (Duo Set Kit from R\&D systems). The limit of detection of the assay is $40 \mathrm{pg} / \mathrm{ml}$ for IL-12 and $30 \mathrm{pg} / \mathrm{ml}$ for IFN-g.

\section{$\mathrm{PGE}_{2}$ measurement}

$\mathrm{PGE}_{2}$ levels were measured directly in the supernatant from uninfected muscle cell cultures and $T$. gondii infected groups after 6, 24 and $48 \mathrm{~h}$ of interaction. The $\mathrm{PGE}_{2}$ was assayed in the cell-free supernatant by enzyme-linked immunoassay (EIA), according to the manufacturer's instructions (Cayman Chemical). The limit of detection of the assay is $15 \mathrm{pg} / \mathrm{ml}$.

\section{Reverse transcriptase polymerase chain reaction (RT-PCR) analysis}

Total RNA was extracted from SkMC culture samples harvested at two different time points from experimental $T$. gondii infection assay (after $3 \mathrm{~h}$ and $24 \mathrm{~h}$ ). For this purpose, $10^{6}$ cells were harvested and washed three times in PBS and centrifuged at 10,000 g. The supernatant was completely removed and the pellet obtained was used for RNA extraction with the RNeasy kit (Qiagen California,
CA, USA), according to the manufactor's recommendations. Total mRNA was measured and cDNA was synthesized using oligo(dT) and Superscript III FirstStrand System (Invitrogen,cat\#18080-051). Real-time PCR was performed on StepOnePlus using Taqman Gene expression assay: COX-2 (Mm01307334_g1) and HPRT1 (Mm01545399_m1) obtained from Applied Biosystems. Efficiency curve showed between $88-92 \%$. All qRT-PCR experiments were performed in duplicate, including notemplate controls. The relative expression of COX-2 was determined using the $2^{(-\mathrm{ddCt})}$ method.

\section{Statistical analysis}

Data were reported as the mean \pm S.E. and were analyzed statistically by means of analysis of variance followed by Student's $t$ test with the level of significance set at $p \leq 0.05$.

\section{Results}

\section{T. gondii infection triggers lipid droplet biogenesis in muscle cells}

In order to detect and quantify the incorporation of neutral lipids and LD biogenesis in uninfected and T. gondii infected cultures, three different lipid markers, BODIPY 493/503 (4,4-difluoro-1,3,5,7,8-pentamethyl-4-bora-3a,4adiaza-s-indacene), Nile Red or osmium $\left(\mathrm{OsO}_{4}\right)$ were used. Mixed cultures containing both SkMC and fibroblasts after $24 \mathrm{~h}$ and $48 \mathrm{~h}$ of cultivation allowed by use of BODIPY a comparative analysis of these cells for the presence of LD. LD revealed by Nile Red stain were distributed throughout the whole cell cytoplasm, sometimes concentrated at the perinuclear region in uninfected SkMC as showed by both interferential and fluorescence microscopy overlay and by confocal microscopy (Figure 1A). After $24 \mathrm{~h}$ of infection, many parasites were observed within the PV in SkMC, with a notable presence of LD around these vacuoles (Figure $1 \mathrm{~B}$ and $\mathrm{C}$ ). We also demonstrated using BODIPY the slight presence of LD in uninfected cultures in myoblasts, myotubes and also fibroblasts, after $96 \mathrm{~h}$ (Figure 2A and B). After $6 \mathrm{~h}$ of interaction with $T$. gondii a remarkable increase of LD biogenesis was observed and its recruitment in T. gondiiinfected SkMC as shown by both interferential (Figure 2C) and confocal microscopy (Figure 2D). However, fibroblasts present in the culture have virtually little or no LD labeling (Figure $1 \mathrm{C}$ ). Besides, it was possible to demonstrate by use of BODIPY in representative images at $24 \mathrm{~h}$ (Figure 3A and $\mathrm{B}$ ) and $48 \mathrm{~h}$ (Figure 3C, D) an increase of LD in infected SkMC, which was time-dependent when analyzed during a period of $6 \mathrm{~h}$ to $48 \mathrm{~h}$ (Figure 4). Figure 3C and D show that fibroblasts present in culture, whether infected or not, show no changes in the LD numbers. The quantitative analysis of experiments using osmium as stain showed that during myogenesis of SkMC, the number of LD remained constant, but there was a significant time- 


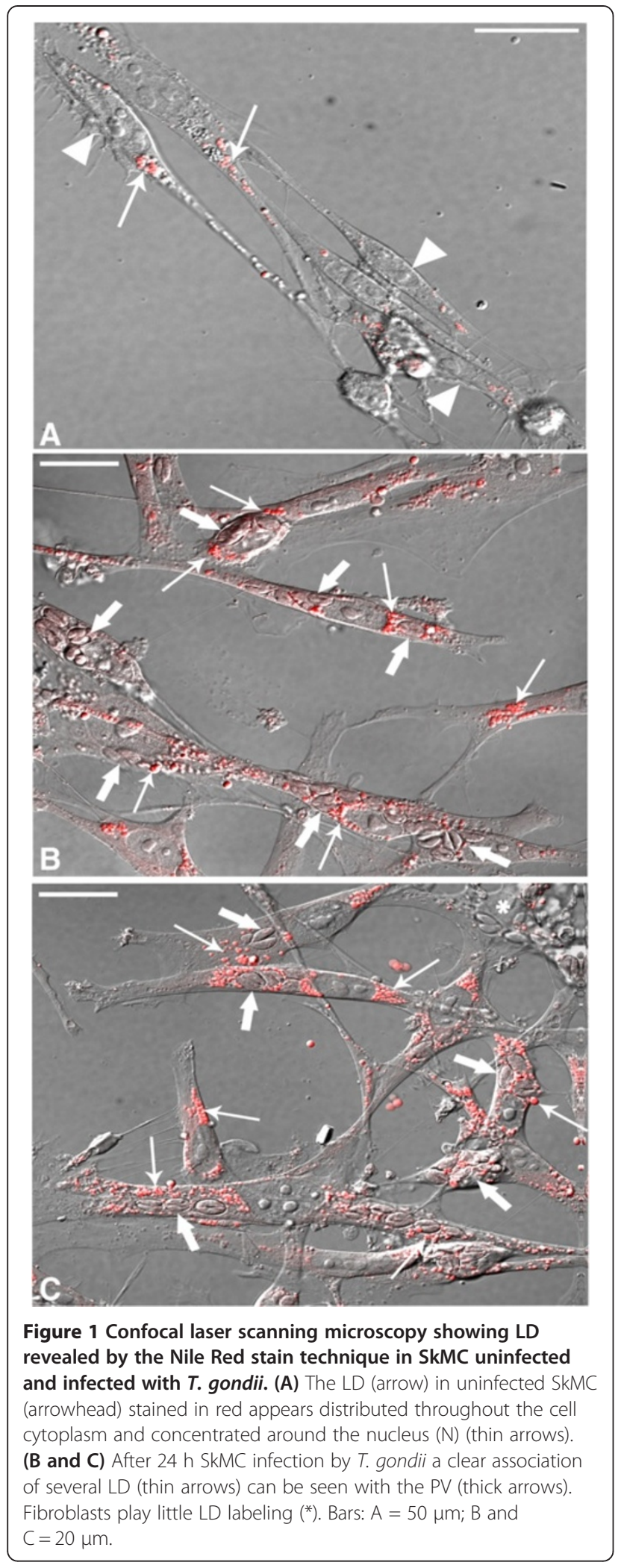

dependent increase of these structures (about 2-3 times) after 6, 24 and $48 \mathrm{~h}$ of interaction with T. gondii (Figure 4). At all times of interaction, in addition to increased LD numbers in observed parasitized SkMC, an increase of about 5.2 times in the LD area was also seen as compared to normal cells $(\mathrm{p}<0.001)$, showing the average size of 22.14 $\mu \mathrm{m}$ in uninfected SkMC and about $115.25 \mu \mathrm{m}$ in infected cells.

\section{Sarcoplasmic reticulum and LD interact in $T$. gondii infection}

To better understand the results observed by fluorescence analysis we also investigated the involvement of LD by electron microscopy. In this ultrathin section the ultrastructural analysis of uninfected SkMC shows no LD (Figure 5A), while the infected muscle cell after $6 \mathrm{~h}$ of interaction displays the VP containing one parasite and the presence of many light dense cytoplasmic structures with a frequent peripheral rim of electron-dense material consistent with LD in the cell cytoplasm, around the VP and in close contact with a typical PVM (Figure 5B). Analysis after $6 \mathrm{~h}$ of interaction shows the conoid of the parasite $(\mathrm{P})$ was in close contact with LD (Figure 6A) and also LD were in intimate contact with the PVM and the membrane of the parasite in Figure 6B and also its integration within the matrix of the vacuole (Figure 6C). After $24 \mathrm{~h}$ of infection several darkened LD, as revealed by the imidazole technique, could be seen in close contact with PV and some LD simultaneously associated to two different PV (Figure 6D), like a bridge connecting them. The ultrastructural cytochemistry of SkMC using the potassium iodide (KI) technique revealed the presence of tubular structures with the electron dense label distributed over the whole cytoplasm and also in the nuclear envelope (Figure 7A). After $4 \mathrm{~h}$ of parasite-SkMC interaction it was noted that the reaction product was localized in structures resembling profiles of sarcoplasmic reticulum (SR), which surrounded the PV, dispersed in the host cell cytoplasm and located around the nucleus, as well as in the inner membrane complex of the parasite (Figure 7B). Precipitation of the reaction product for KI could also be observed inside the PV and in association with the PVM and also LD, as revealed by the imidazole technique (Figure 7C). SkMC after $24 \mathrm{~h}$ of parasite-host cell interaction showed cells containing two or more parasites with reaction product for KI surrounding the nucleus of SkMC and in vesicles inside the vacuole containing $T$. gondii (Figure 7D).

\section{T. gondii infection induces cytokine production in skeletal muscle cells}

In this study we addressed whether SkMC could produce the cytokines IL-12 and INF-g during myogenesis and $T$. gondii infection. SkMC showed a gradual decrease in the 

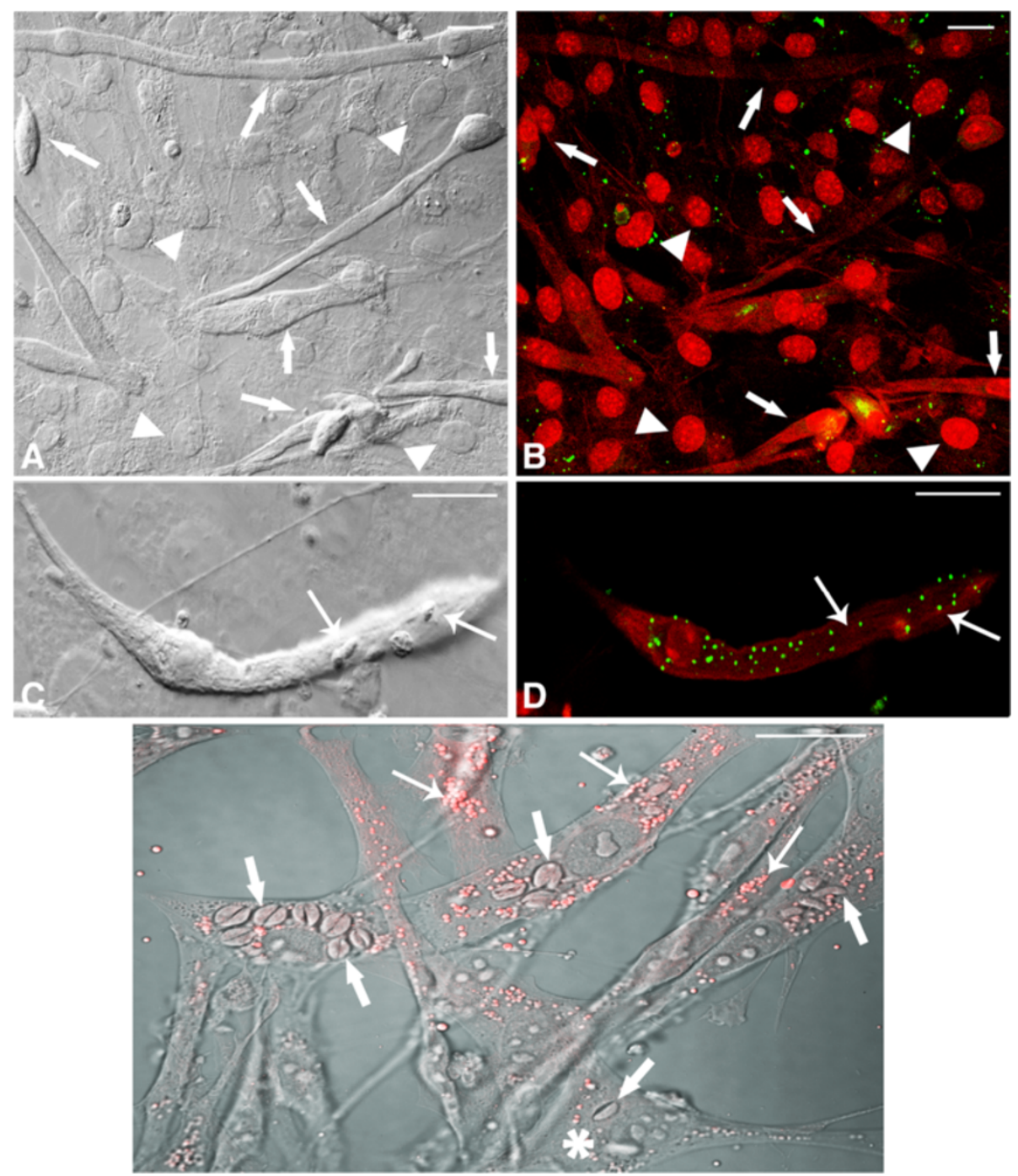

Figure 2 Confocal Laser Scanning Microscopy showing LD revealed by BODIPY in uninfected and T. gondii-infected SkMC for different periods of interaction. (A) Control - interferential microscopy revealing the profile of uninfected culture with the presence of myoblasts (double arrows), multinucleated myotubes (arrows) and fibroblasts (arrowhead). (B) Merge showing double marking for actin cytoskeleton and nuclei SkMC (arrows) in red and LD in green. Note discrete distribution of LD across culture. (C) Interferential microscopy showing parasites in T. gondii-infected SkMC (thick arrows) after $6 \mathrm{~h}$ of the interaction. (D) Merge showing actin cytoskeleton and nuclei in red and LD in green in T. gondii-infected SkMC. All bars $=20 \mu \mathrm{m}$.

synthesis of IL-12, five days after cultivation. However, in $T$. gondii infected-cell cultures, after 6, 24 and 48 h of interaction a significant increase in the production of this cytokine occurred as compared with control. Higher levels of IL-12 were observed in earlier periods of infection analyzed, which were reduced after $48 \mathrm{~h}$ of infection (Figure 8A). Increased INF-g levels were verified in the supernatant of $T$. gondii-infected SkMC in all periods analyzed (Figure 8B).

\section{T. gondii infection induces eicosanoid generation in} skeletal muscle cells

Lipid droplets are stores of the eicosanoid precursor arachidonic acid in different leukocyte subsets, including eosinophils, neutrophils, and monocytes, and contain eicosanoid-forming enzymes [12,22]. In this way, we investigated whether T. gondii-infected SkMC would lead to enhanced $\mathrm{PGE}_{2}$ production. $\mathrm{PGE}_{2}$ quantified in the supernatant from non-infected and infected muscle cells cultured with $T$. gondii after 6,24 and $48 \mathrm{~h}$ of interaction and measured by enzyme-linked immunoassay, showed a significant time-dependent increase in $\mathrm{PGE}_{2}$ generation from $6 \mathrm{~h}$ up to $48 \mathrm{~h}$, that parallel and positively correlated with LD formation in $T$. gondii-infected muscle cells but not in uninfected cells (Figure 9A). T. gondii infection also triggered a time-dependent increase of COX-2 expression (Figure 9B). 

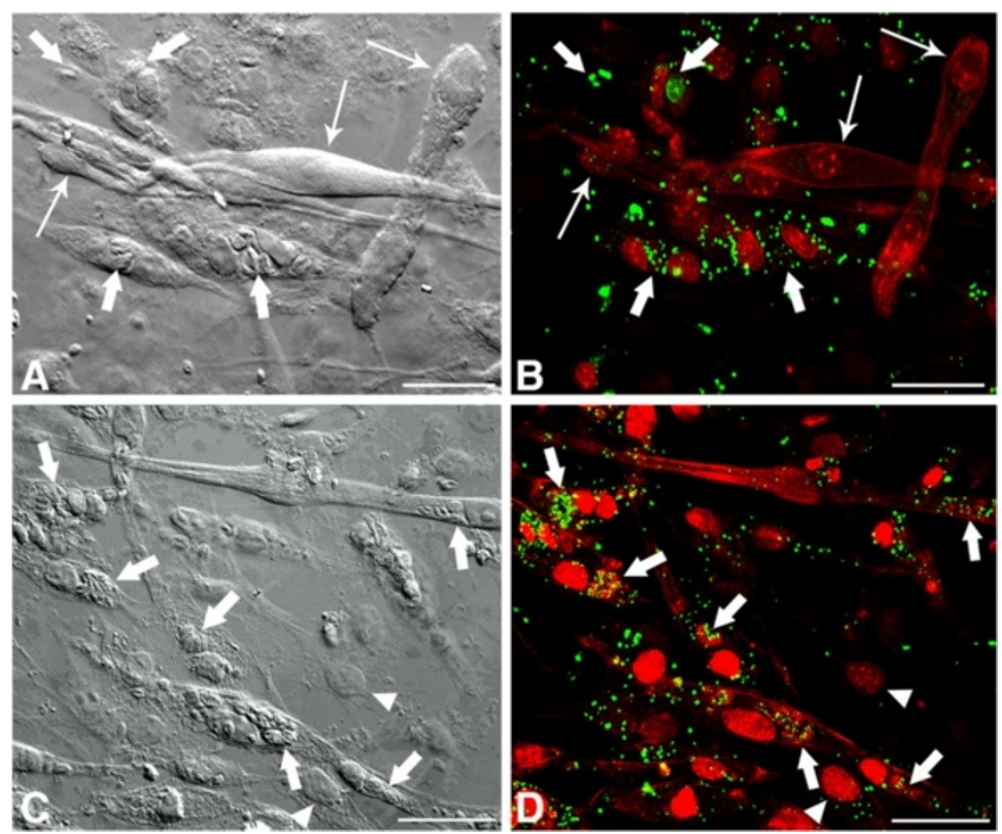

Figure 3 Confocal Laser Scanning Microscopy analysis showing LD revealed by BODIPY in T. gondii-infected SkMC after 24 and 48 h of interaction. (A) Image by interferential microscopy showing T. gondii-infected SkMC after $24 \mathrm{~h}$. Note the presence of infected myotubes (thick arrows) and uninfected (thin arrows) in the same culture. (B) Uninfected myotubes (thin arrows) practically does not present LD while cells infected with T. gondii (thick arrows) have numerous LD in green. (C) Interferential microscopy showing T. gondii-infected SkMC after 48 h. Note the presence of infected cells (thick arrows). (D) Double staining T. gondii-infected SkMC in red and LD in green (arrows). Note the major concentration of LD mainly in infected SkMC. Fibroblasts in culture present few LD infected or not (arrowhead). All bars $=20 \mu \mathrm{m}$.

\section{Discussion}

It is known that $T$. gondii mobilizes lipids resources from the host cells during invasion and its intracellular cycle [4], and although the parasite does not synthesize its own cholesterol it has evolved strategies to divert host cell lipid metabolism to favor its survival [1,7]. Our results suggest that $T$. gondii-infected SkMC increases

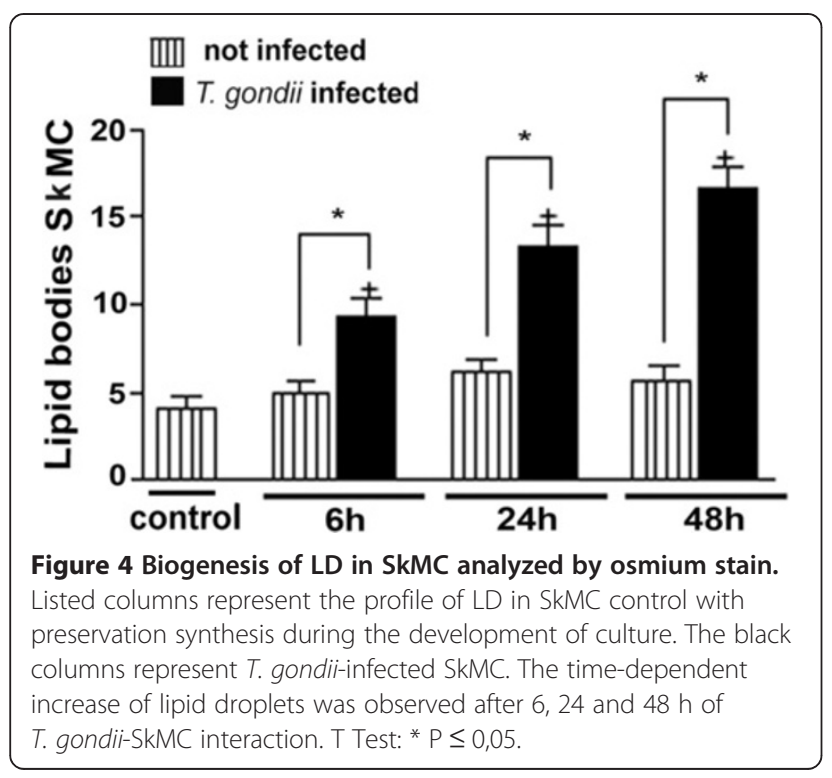

the synthesis of LD as well as their content, providing lipids to the parasite and thus contributing to the growth and maturation of the parasitophorous vacuole, as described in another cellular model by Caffaro et al. [38]. Initially using the fluorescent dye Nile Red, it was possible to observe the increased formation of LD within the first hour of $T$. gondii-SkMC interaction and also the presence of LDs next to the parasite, and at $24 \mathrm{~h}$ around the PV.

Our quantitative data showed that $T$. gondii infection triggers biogenesis of LD within muscle cells. The analysis by light and fluorescence microscopy of $T$. gondii-infected SkMC stained with osmium tetroxide or BODIPY clearly showed an increase in the number of LD after 6, 24 and $48 \mathrm{~h}$ of the interaction. We suggest that Toxoplasma may be interfering with the lipid metabolism of the host cell stimulating its synthesis. Previous studies have shown sequestration of some phospholipids by Toxoplasma infection whilst in the host cell in order to construct more complex lipids $[4,41]$. In our experiments it was observed that in $T$. gondii-infected SkMC, significant increase in the formation of the LD occurs at all times of interaction: 6, 24 and $48 \mathrm{~h}$. It is known that muscle cells may accumulate phospholipids, triacylglycerol and cholesterol in LD, which could have roles in the regulation of cell cycle, migration and myogenesis by activation of proteolytic systems such as the calpain system $[42,43]$. Thus, we do not discard the 


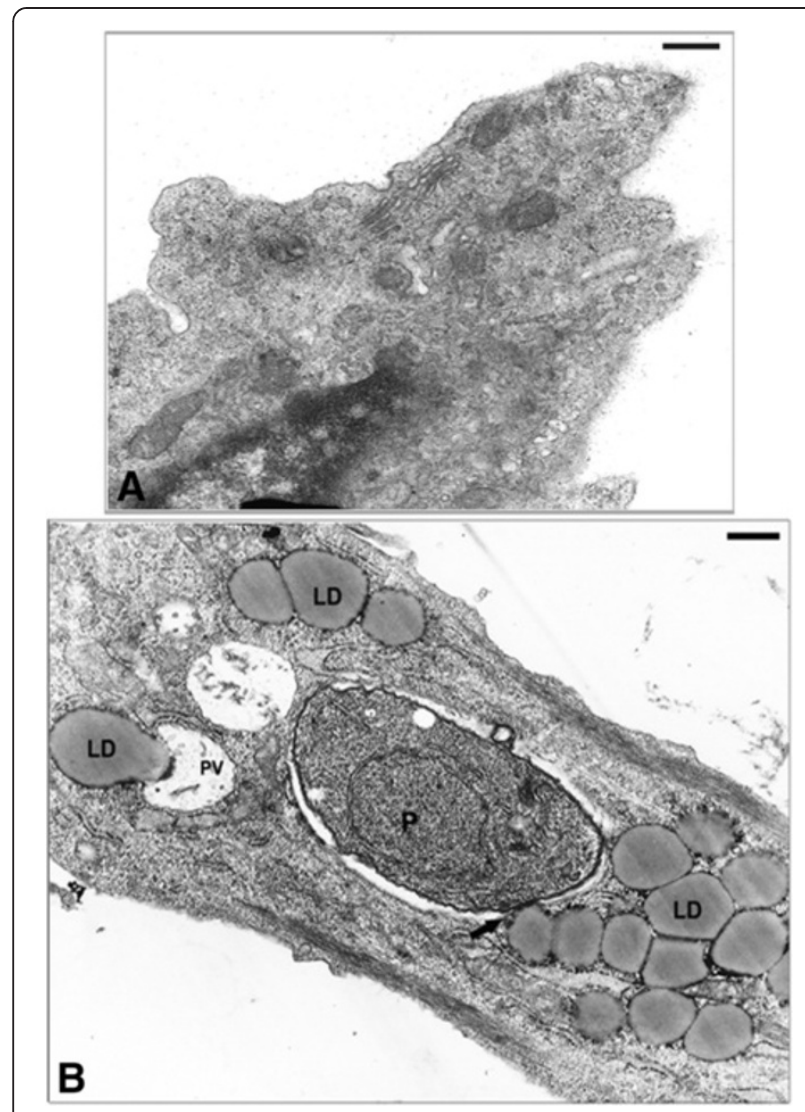

Figure 5 Ultrastructure of SkMC in cultures. (A) Uninfected cells without LD. (B) Note the large amount of lipid droplets during the first $6 \mathrm{~h}$ of T. gondii-SkMC interaction. All bars $=10 \mu \mathrm{m}$.

hypothesis that the recruitment of LD by the parasite during its replication, could lead to an increase of LD synthesis by the host cell to maintain homeostasis of their vital activities. The homeostasis is maintained by a balance between the cholesterol internalized via the LDL receptor and synthesis involving the enzyme: 3-hydroxy-3-methylglutaryl-coenzyme A reductase (HMG-CoA) [44]. In cells infected by $T$. gondii, there is an increase in the synthesis of receptors for internalization of LDL [1], and the activity of HMG-CoA is four times higher [45].

Our ultrastructural cytochemistry analysis demonstrated, for the first time, the direct contact of LD with the vacuolar membrane, its matrix as well as with the parasite membrane during its segregation inside the PV. Studies show the involvement of ER from the host cell in the biogenesis of LD [21]. This supplement of lipids could contribute to the increase of the vacuole membrane area during the intracellular development of $T$. gondii $[6,38]$. LD structure and composition, as determined in different cell types and conditions, consists of cholesteryl esters and triglycerides surrounded by a single monolayer of phospholipids and contains a variable array of proteins [19,21]. We believe that this recruitment of LD by $T$. gondii may
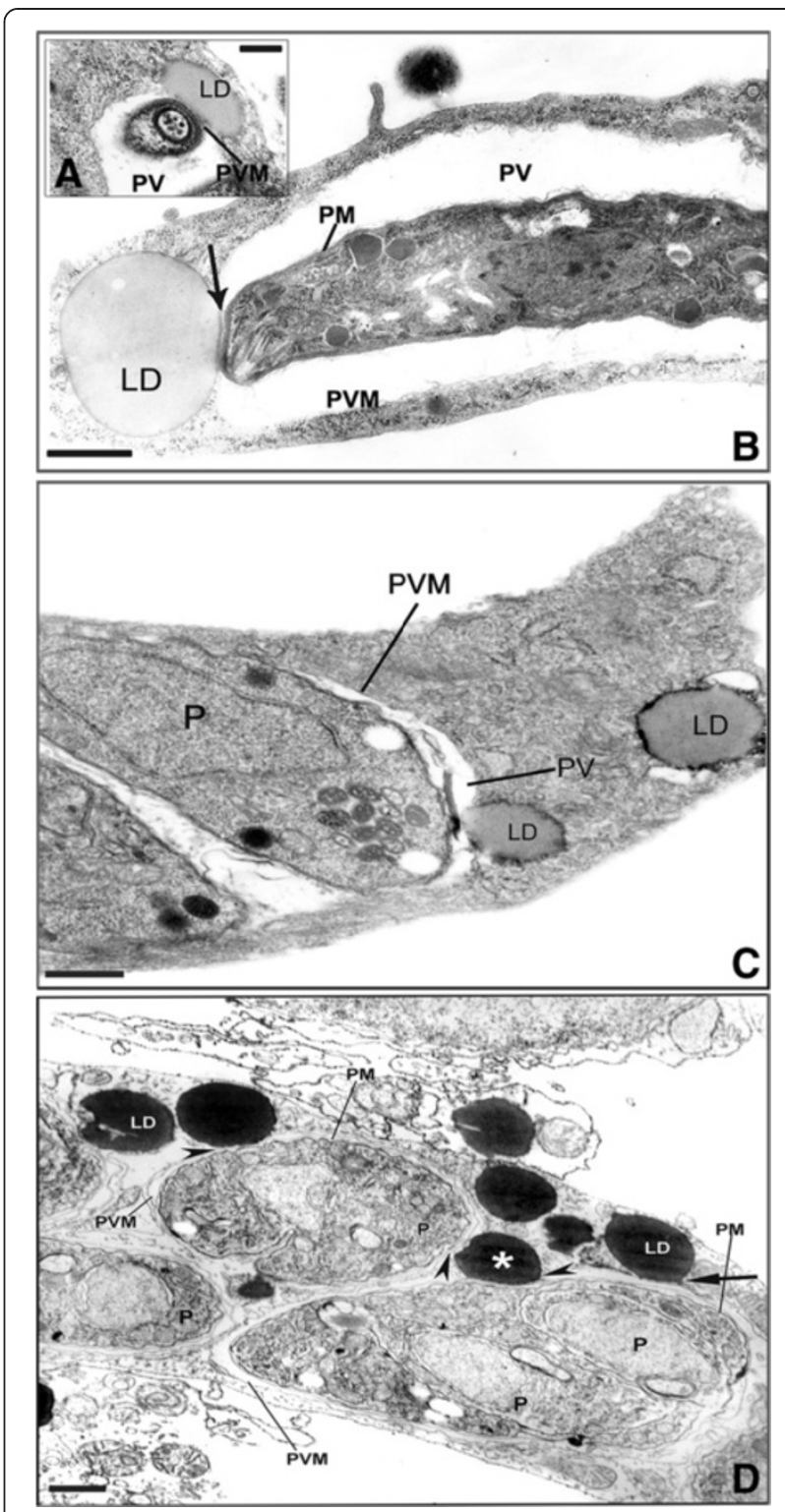

Figure 6 Ultrastructural analysis of T. gondii-SkMC interaction. (A) The conoid of the parasite (P) was in close contact with LD; (B and C) Images showing a large lipid droplets (LD) in closed contact with the parasitophorous vacuole (PV) after $12 \mathrm{~h}$ of T. gondii SkMC interaction, respectively. and also vacuolar matrix (D) After $24 \mathrm{~h}$ SkMC infection by T. gondii a clear association of several LD revealed by imidazole can be seen in connection with two PV (asterisks). PM: parasite membrane; PVM: parasitophorous vacuole membrane. Bars: $A=0.2 \mu \mathrm{m} ; \mathrm{B}-\mathrm{D}=1 \mu \mathrm{m}$.

be involved in a survival strategy to surmount the deficiency of cholesterol and other lipids by the parasite.

The mechanism by which host-cell-derived lipids are transferred across the PVM to the parasite is uncertain [4]. In addition to LD recruitment, our data clearly demonstrated: (i) the discharge of the SR to the interior of the $\mathrm{PV}$ after $4 \mathrm{~h}$ of $T$. gondii-SkMC infection; (ii) the presence of vesicles with different diameters and morphology 

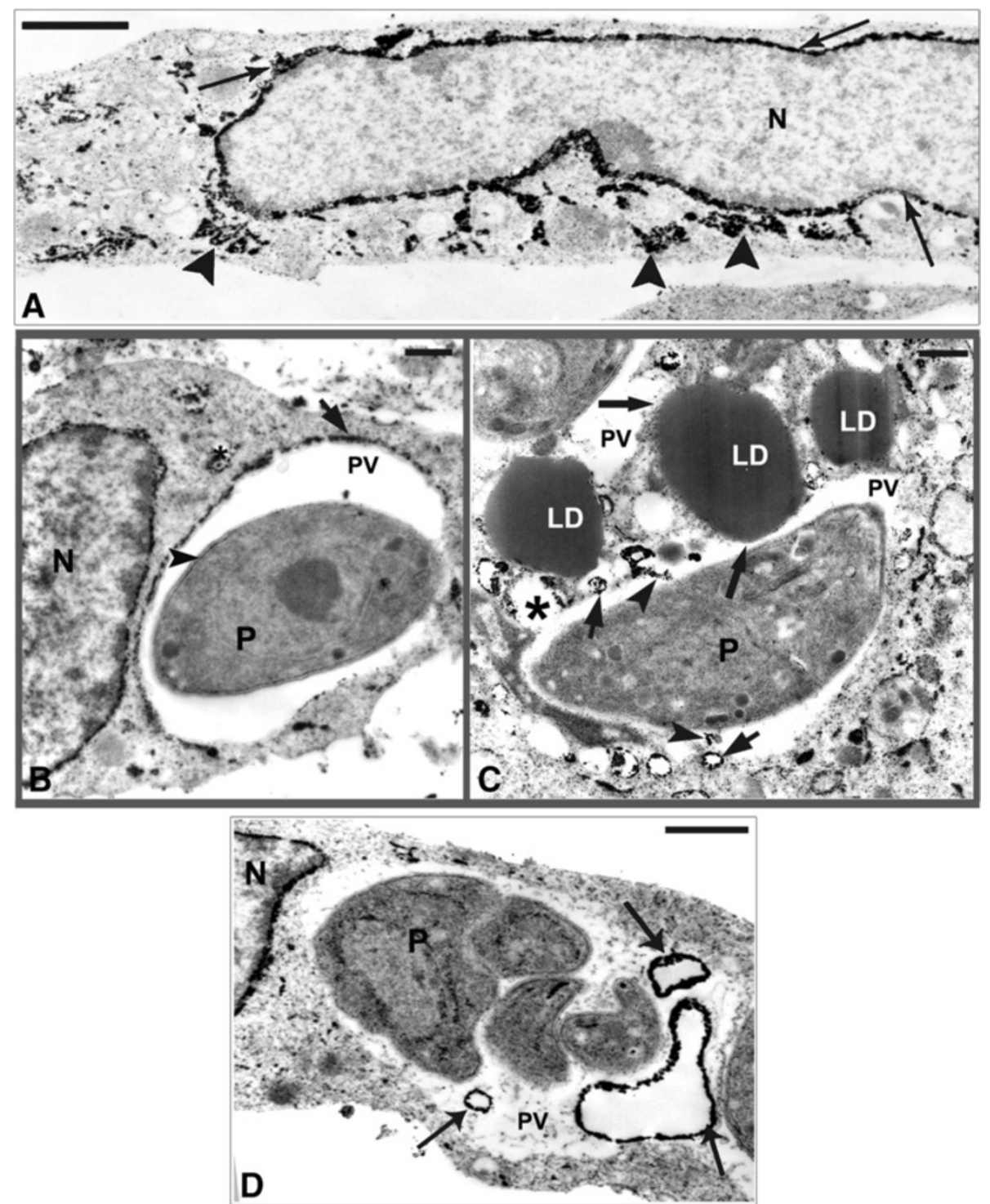

Figure 7 Ultrastructural cytochemistry using potassium iodide (KI) for detection of sarcoplasmic reticulum (SR). (A) SR profiles from uninfected SkMC displaying positive reaction products for KI around the nucleus (N) (arrow) and in the cytoplasm (arrowhead). (B) SkMC infected for $4 \mathrm{~h}$ with $\mathrm{T}$. gondii shows the presence of SR profiles containing the reaction product for $\mathrm{Kl}$ in the cytoplasm (asterisk) surround the nucleus (N) and the PV (arrow). Demarcation in the complex internal membrane of the parasite could also be observed (arrowhead). (C) Profiles of SR revealed by KI (small arrow) are observed near and in fusion processes with PV (asterisk) and also inside the PV (arrowhead). Association of several lipid droplets (LD) darkened - revealed by imidazole technique can be seen with the PVM (thick arrow). (D) After $24 \mathrm{~h}$ of T. gondii-SkMC interaction several parasites were observed within the PV containing vesicles of different morphologies and sizes labeled with $\mathrm{KI}$ (arrows) and around the nucleus (N). Bars: $A=50 \mu \mathrm{m} ; \mathrm{B}$ and $\mathrm{C}=0.5 \mu \mathrm{m} ; \mathrm{D}=1 \mu \mathrm{m}$.

containing the reaction product for KI localized inside the vacuole after $24 \mathrm{~h}$ of parasite-host cell infection. These results are similar to that described by PuzianowskaKuznicka and Kuznicki [46] who observed by immunoelectron microscopy the transfer of SR components into the PV, indicating that the fusion occurs between the two compartments and, (iii) the accentuated decrease of the SR demarcation around the PV, after $24 \mathrm{~h}$ of infection. This data suggests that components of the SR can be incorporated by the intracellular parasites, constituting a source of nutrients and lipid possibly for its development, as proposed previously $[4,46]$.

The ER plays a crucial role in cytoplasmic signaling in a variety of cells. It is particularly relevant to SkMC, where this organelle constitutes the main $\mathrm{Ca}^{2+}$ store for essential functions, such as contraction $[47,48]$. Our results by electron microscopy showed total reorganization of the SR in T. gondii-infected SkMC. Thus, we believe 


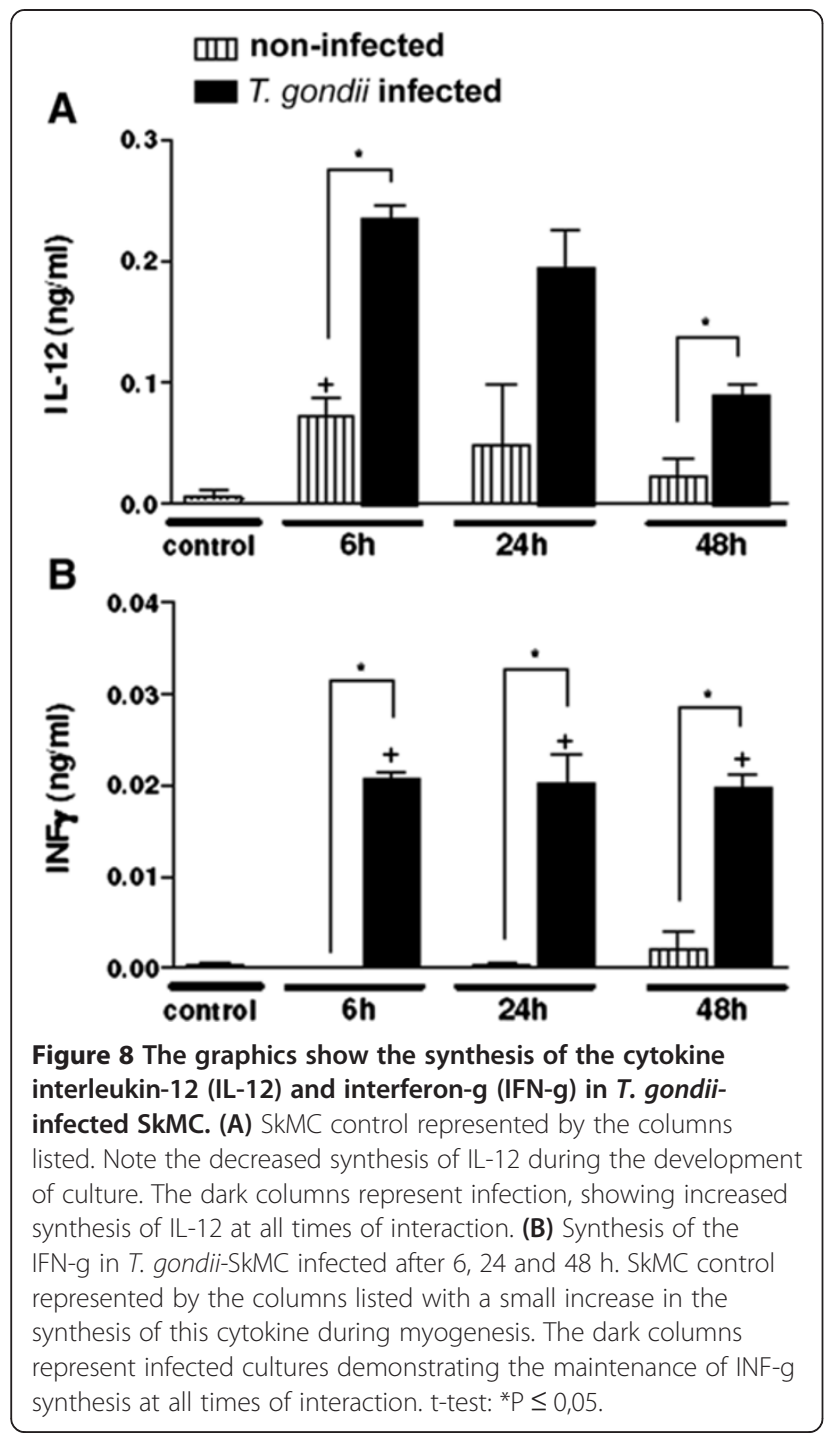

that this phenomenon may lead to changes in $\mathrm{Ca}^{2+}$ homeostasis compromising the functionality of SkMC. The importance of juxtapositioning of SR, mitochondria and transverse tubules (T-tubules) in muscle cell for better communication between sites of $\mathrm{Ca}^{2+}$ release which ensures the contraction of myofibrils are described. Therefore, we suggest that $T$. gondii may be benefiting from the repositioning of the SR sequestered, not only lipids, but also from the $\mathrm{Ca}^{2+}$ not used by sarcomeres [49].

The accumulation of the LD within leukocytes in inflammatory conditions for example: bacterial sepsis, allergic lung inflammation, arthritis, and in mycobacterium infections among others has recently been reported [21]. However, mechanisms that regulate LD formation and its functional significance to the cellular biology in $T$. gondii infection are not known.

Increased $\mathrm{PGE}_{2}$ production in pathological conditions is largely regulated by COX-2 gene induction [23]. By using

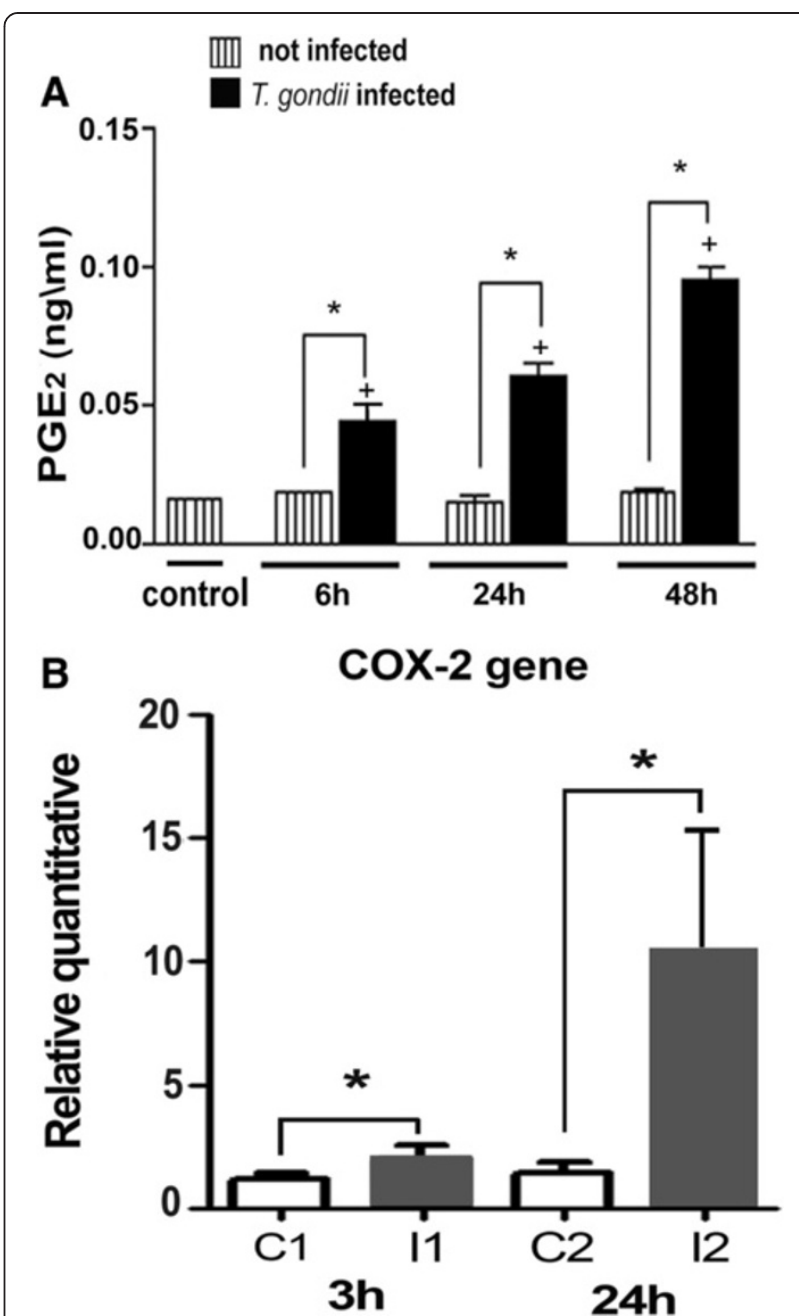

Figure $9 \mathrm{PGE}_{2}$ generation and COX-2 gene expression in $T$. gondii-infected SkMC. (A) Synthesis of PGE 2 by EIA. The listed columns represent SkMC control with approximate values in all points. The black columns show infected cultures where there is a time-dependent increase in the production of $\mathrm{PGE}_{2}$. (B) Representation of COX-2 gene expression by RT-PCR in T. gondii-infected SkMC after 3 and $24 \mathrm{~h}$. The white columns represent SkMC control with approximate values in all points. The gray columns show infected muscle cells where there is a time-dependent increase in the production of COX-2 gene. t- test: ${ }^{*} \mathrm{P} \leq 005$.

qRT-PCR the expression of COX-2 gene was analyzed, showing that after 3 and $24 \mathrm{~h}$ of $T$. gondii-SkMC interaction, the COX-2 expression was up regulated. Studies have demonstrated that the promoter region of COX-2 has several potential regulatory elements, which can affect gene transcription [50]. In pancreatic beta-cells several transcription factors regulate $\mathrm{COX}-2$ gene expression as for example, the signal transducer and activator of transcription 1 (STAT1) that plays a negative role on COX-2 promoter [23]. It was described that $T$. gondii can also manipulate the host transcription factors, including inhibiting STAT1 [3]. Thus, we suggest that the presence of $T$. gondii 
in SkMC may be inducing the increased COX-2 expression, but whether or not the inhibition of STAT1 also occurs in this process still remains uncertain.

Several studies have demonstrated that an increase of LD numbers produced during infections by different pathogens is related to the increased generation of eicosanoids due to the compartmentalization of the substrate arachidonic acid and the eicosanoid-forming enzymes within newly formed LDs and LDs are major sites of eicosanoid production in different inflammatory conditions $[12,17,18,21,22]$. Our results show an increase of $\mathrm{PGE}_{2}$ synthesis, from $6 \mathrm{~h}$ up to $48 \mathrm{~h}$ of $T$. gondii- SkMC infection. Of note, the $T$. gondii-induced increased $\mathrm{PGE}_{2}$ generation occurs in parallel and positively correlates to the increased formation of LDs, suggesting that LDs may have roles in the heightened eicosanoid production during T. gondii infection. However, future studies will be necessary to confirm the involvement of LDs in the $\mathrm{PGE}_{2}$ production triggered by $T$. gondii. Among other factors, we believe that the success of the infection of $T$. gondii in the muscle tissue may be related to the increased COX-2 expression, compartmentalization within LD and consequently enhanced production of the eicosanoid $\mathrm{PGE}_{2}$. In other cell types, studies showed that the enzymatic conversion of free arachidonic acid into prostaglandin down-modulates the cell-mediated response favoring not only intracellular pathogens, but also the survival of the host $[51,52]$. Indeed, high concentrations of $\mathrm{PGE}_{2}$ potently inhibit the Th1 type response, tumor necrosis factor (TNF) and nitric oxide (NO) production, and these changes favor intracellular parasite growth $[53,54]$.

It is worth remembering that SkMC is not a cell of the immune system. The levels of inflammatory markers $\left(\mathrm{PGE}_{2}\right.$ and COX-2) observed in SkMC in our assays are considered quantitatively lower when compared to levels produced by macrophages, despite their increase during Toxoplasma infection [52]. We believe that a moderate SkMC immune response may suppress the replication of parasites favoring the bradyzoite conversion, while a strong immune response may change the cell cycle progression parasite or act as a microbicide activator [55]. These data support our hypothesis that the recruitment of LD by $T$. gondii, together with the cellular response, may possibly be related to the development of the chronic phase in SkMC.

Accordingly, intracellular pathogens-induced increased LD formation during intracellular infection, including $T$. cruzi, M. bovis BCG and M. leprae favouring intracellular pathogen survival through mechanisms which involve LDderived eicosanoid formation and LD recruitment towards the phagosome $[12,14,17]$. Similarly, we describe here that the enhanced capacity of muscle cells to generate $\mathrm{PGE}_{2}$ in the course of the $T$. gondii infection correlates to the increased LD formation. And so, the recruitment of organelles such as LD and SR by the parasite during its host cell interaction, may contribute to the mechanisms that intracellular pathogens have evolved to survive in host cells. Future studies are necessary to characterize the regulation and function of the prostaglandins in SkMC and to understand if the presence of SR in PV may be acting as a source of $\mathrm{Ca}^{2+}$ that facilitates the preference of muscle tissue in the development phase of chronic toxoplasmosis.

In our experiments we observed that $\mathrm{SkMC}$ is capable of producing levels of the cytokines IL-12 and IFN-g with a significant increase in their synthesis after 6,24 and $48 \mathrm{~h}$ of interaction with $T$. gondii. Our results corroborate with studies that show the muscle as a cytokine producer by myokines [56]. IL-6 was the first cytokine to be discovered being produced by muscle cells; however, skeletal muscles may produce and express different cytokines families $[24,25]$. Some authors describe that concerning the synthesis of IFN-g, T. gondii-infected SkMC are able to develop a strong anti-parasitic response, reducing significantly the growth of the parasite [25]. Experiments using mice lacking IFN-g [57] and IL-12 showed absence of appropriate immunity, which rapidly leads to host death [58]. It is most advantageous for the Toxoplasma to keep its host alive until transmission to another host through oral transmission of tissue cysts.

IFN-g is known to induce an inflammatory response and control of parasite load during the early stages of infection [59]. During Toxoplasma infection, the host immune response is dependent on IFN-g induced by IL-12 production in a variety of cell types. In our study, in the course of myogenesis of SkMC the levels of IFN-g did not change, whereas the concentration of these cytokines increased in all times of interaction with $T$. gondii analyzed. However, in other cellular models such as macrophages, neutrophils and especially dendritic cells, Lang et al. [60] described that $T$. gondii inhibits production of IL-12. Nickdel et al. [61] showed that during the early stage of oral infection with $T$. gondii an increase in small-intestine pathology occurred, in addition a reduction in the levels of plasma IL-12 and IFN-g levels was observed. Moreover, Matowicka-Karna et al. [62] studying a group of patients infected with $T$. gondii, also noted a decrease in IL-12 levels. We believe that the increase in cytokines IFN-g and IL-12 in SkMC-T. gondii infected cells may be related to manipulation of transcription factors of the host by Toxoplasma early on the infection as shown by our results after 3 hours of interaction. Moreover, the increased synthesis of IFN-g [25] and IL-12 may be act by reducing the multiplication process of tachyzoites forms (acute phase) favoring, the differentiation to bradyzoites forms, found in tissue cysts (chronic phase).

Cheng et al. [26] have shown that IFN-g expression is upregulated in skeletal muscle following injury. It is of interest to the parasite that the host cell remains alive, 
thus increasing the synthesis of a cytokine that is involved in the repair and homeostasis of the host cell and may act as a strategy that favors $T$. gondii maintenance. So, Toxoplasma has evolved to exploit own molecules and cellular response of the host, providing a favorable environment for the establishment of chronic infection in SkMC.

Finally, SkMC can be used as an important cellular model for studies on the molecular mechanisms in response to parasitism by $T$. gondii, mainly considering its importance as a target cell for encystment and its role in the transmission of the parasite.

\section{Conclusions}

In conclusion, our data demonstrated that $T$. gondii infection in muscle cells causes a pronounced effect on hostcell lipid metabolism through regulation of LD biogenesis and recruitment of these organelles to PV. The increased LD formation may potentially act as source of prostaglandin production with implications to the host immune response and could represent a source of lipids and other nutrients for parasite survival. Thus, the increase the LD, followed by expression of COX-2 and $\mathrm{PGE}_{2}$ in the SkMC may be contributing to the control of the synthesis of IL12 and IFN-g during infection by $T$. gondii. We believe that the increase of these cytokines involved in the repair, and homeostasis of muscle cells after injury, might contribute to the establishment and maintenance of the chronic phase of T. gondii infection in SkMC.

\section{Competing interests}

The authors declare that they have no competing interests.

\section{Authors' contributions}

HSB conceived, participated in the design and coordination of the study and had the general supervision and complete overview of the project. AFG co-conceived the study, carried out most of the experimental work, including the processing of samples and the final illustrations for the manuscript, analyzed data and drafted the manuscript, as part of her PhD thesis. RM participated in the electron microscopy assays. LC participated in the design of the study. RMR carried out the molecular assays. KGM and PTB made substantial contributions to data acquisition, analysis and participated in the revision of the manuscript. All authors analyzed the data and read and approved the final version of the manuscript.

\section{Acknowledgments}

The authors thank Carlos Alberto Bizarro Rodrigues from Farmanguinhos/ Fiocruz for the production of interferential microscopy images for the aid with confocal microscopy. We are grateful to Sandra Maria de Oliveira Souza and Genesio Lopes de Faria for technical assistance. This work was supported by grants from Conselho Nacional de Desenvolvimento Científico e Tecnológico (CNPq), Fundação Carlos Chagas Filho de Amparo à Pesquisa do Estado do Rio de Janeiro (FAPERJ), Universidade do Estado do Rio de Janeiro (UERJ), Fundação Oswaldo Cruz (Programa Estratégico de Apoio à Pesquisa em Saúde - PAPES VI), Pronex - Programa de Apoio a Núcleos de Excelência - CNPq/FAPERJ and Instituto Oswaldo Cruz/Fiocruz.

\section{Author details}

'Laboratório de Biologia Estrutural, Instituto Oswaldo Cruz, Fundação Oswaldo Cruz, Rio de Janeiro, Brazil. ${ }^{2}$ Laboratório de Imunologia e Inflamação, Universidade de Brasília, Brasília, Brazil. " ${ }^{3}$ Laboratório Cultura de Células, Depto. Histologia e Embriologia, Instituto de Biologia, Universidade do Estado do Rio de Janeiro, Rio de Janeiro, Brazil. ${ }^{4}$ Laboratório de Imunofarmacologia, Instituto Oswaldo Cruz, Fundação Oswaldo Cruz, Rio de Janeiro, Brazil.

Received: 2 December 2013 Accepted: 21 January 2014

Published: 23 January 2014

\section{References}

1. Coppens I, Sinai AP, Joiner KA: Toxoplasma gondii exploits host lowdensity lipoprotein receptor-mediated endocytosis for cholesterol acquisition. J Cell Biol 2000, 149:167-180.

2. Andrade EF, Stumbo AC, Monteiro-Leal LH, Carvalho L, Barbosa HS: Do microtubules around the Toxoplasma gondii-containing parasitophorous vacuole in skeletal muscle cells form a barrier for the phagolysosomal fusion? I Submicrosc Cytol Pathol 2001, 33:337-341.

3. Laliberté J, Carruthers VB: Host cell manipulation by the human pathogen Toxoplasma gondii. Cell Mol Life Sci 2008, 65:1900-1915.

4. Charron AJ, Sibley LD: Host cells: mobilizable lipid resources for the intracellular parasite Toxoplasma gondii. J Cell Sci 2002, 115:3049-3059.

5. Nishikawa Y, Ibrahim HM, Kameyama K, Shiga I, Hiasa J, Xuan X: Host cholesterol synthesis contributes to growth of intracellular Toxoplasma gondii in macrophages. J Vet Med Sci 2011, 73:633-639.

6. Sinai AP: Biogenesis of and activities at the Toxoplasma gondii parasitophorous vacuole membrane. Subcell Biochem 2008, 47:155-164.

7. Portugal $L R$, Fernandes LR, Pietra Pedroso VS, Santiago HC, Gazzinelli RT, Alvarez-Leite J: Influence of low-density lipoprotein (LDL) receptor on lipid composition inflammation and parasitism during Toxoplasma gondii infection. Microbes Infect 2008, 10:276-284.

8. D'Avila H, Maya-Monteiro CM, Bozza PT: Lipid bodies in innate immune response to bacterial and parasite infections. Int Immunopharmacol 2008, 8:1308-1315.

9. van der Meer-Janssen YP, van Galen J, Batenburg JJ, Helms JB: Lipids in host-pathogen interactions: pathogens exploit the complexity of the host cell lipidome. Prog Lipid Res 2010, 49:1-26.

10. Russell DG, Cardona PJ, Kim MJ, Allain S, Altare F: Foamy macrophages and the progression of the human tuberculosis granuloma. Nat Immunol 2009, 10:943-948.

11. Cáceres N, Tapia G, Ojanguren I, Altare F, Gil O, Pinto S, Vilaplana C, Cardona PJ: Evolution of foamy macrophages in the pulmonary granulomas of experimental tuberculosis models. Tuberculosis 2009, 89:175-182.

12. D'Avila H, Melo RC, Parreira GG, Werneck-Barroso E, Castro-Faria-Neto HC, Bozza PT: Mycobacterium bovis bacillus Calmette-Guérin induces TLR2-mediated formation of lipid bodies: intracellular domains for eicosanoid synthesis in vivo. J Immunol 2006, 176:3087-3097.

13. Almeida PE, Silva AR, Maya-Monteiro CM, Töröcsik D, D'Avila H, Dezsö B, Magalhães KG, Castro-Faria-Neto HC, Nagy L, Bozza PT: Mycobacterium bovis bacillus Calmette-Guérin infection induces TLR2-dependent peroxisome proliferator-activated receptor gamma expression and activation: functions in inflammation, lipid metabolism, and pathogenesis. $\mathrm{J}$ Immunol 2009, 183:1337-1345.

14. Mattos KA, Lara FA, Oliveira VG, Rodrigues LS, D'Avila H, Melo RC, Manso PP, Sarno EN, Bozza PT, Pessolani MC: Modulation of lipid droplets by Mycobacterium leprae in Schwann cells: a putative mechanism for host lipid acquisition and bacterial survival in phagosomes. Cell Microbiol 2011, 13:259-273.

15. Cocchiaro JL, Kumar Y, Fischer ER, Hackstadt T, Valdivia RH: Cytoplasmic lipid droplets are translocated into the lumen of the Chlamydia trachomatis parasitophorous vacuole. Proc Natl Acad Sci U S A 2008, 105:9379-9384.

16. Jackson KE, Klonis N, Ferguson DJ, Adisa A, Dogovski C, Tilley L: Food vacuole-associated lipid bodies and heterogeneous lipid environments in the malaria parasite Plasmodium falciparum. Mol Microbiol 2004, 54:109-122.

17. Melo RC, D'Avila H, Fabrino DL, Almeida PE, Bozza PT: Macrophage lipid body induction by Chagas disease in vivo: putative intracellular domains for eicosanoid formation during infection. Tissue Cell 2003, 35:59-67.

18. D'Avila H, Freire-de-Lima CG, Roque NR, Teixeira L, Barja-Fidalgo C, Silva AR, Melo RC, Dosreis GA, Castro-Faria-Neto HC, Bozza PT: Host cell lipid bodies triggered by Trypanosoma cruzi infection and enhanced by the uptake of apoptotic cells are associated with prostaglandin E2 generation and increased parasite growth. J Infect Dis 2011, 204:951-961. 
19. Tauchi-Sato K, Ozeki S, Houjou T, Taguchi R, Fujimoto T: The surface of lipid droplets is a phospholipid monolayer with a unique fatty acid composition. J Biol Chem 2002, 277:44507-44512.

20. Martin S, Parton RG: Lipid droplets: a unified view of a dynamic organelle. Nat Rev Mol Cell Biol 2006, 7:373-378.

21. Bozza PT, Magalhães KG, Weller PF: Leukocyte lipid bodies - Biogenesis and functions in inflammation. Biochim Biophys Acta 2009, 1791:540-551.

22. Pacheco P, Bozza FA, Gomes RN, Bozza M, Weller PF, Castro-Faria-Neto HC, Bozza PT: Lipopolysaccharide-induced leukocyte lipid body formation in vivo: innate immunity elicited intracellular loci involved in eicosanoid metabolism. J Immunol 2002, 169:6498-6506.

23. Zhang $X$, Zhang J, Yang $X$, Han $X$ : Several transcription factors regulate COX-2 gene expression in pancreatic beta-cells. Mol Biol Rep 2007, 34:199-206.

24. Nielsen S, Pedersen K: Skeletal muscle as an immunogenic organ. Curr Opin Pharmacol 2008, 8:346-351.

25. Takács AC, Swierzy IJ, Lüder CG: Interferon- $\gamma$ restricts Toxoplasma gondii development in murine skeletal muscle cells via nitric oxide production and immunity-related GTPases. PLoS One 2012, 7:e45440.

26. Cheng M, Nguyen MH, Fantuzzi G, Koh TJ: Endogenous interferon-gamma is required for efficient skeletal muscle regeneration. Am J Physiol Cell Physiol 2008, 294:1183-1191.

27. Ferreira-da-Silva MF, Barbosa HS, Gross U, Lüder CG: Stress-related and spontaneous stage differentiation of Toxoplasma gondii. Mol Biosyst 2008, 4:824-834.

28. Cañedo-Solares I, Calzada-Ruiz M, Ortiz-Alegría LB, Ortiz-Muñiz AR, Correa D: Endothelial cell invasion by Toxoplasma gondii: differences between cell types and parasite strains. Parasitol Res 2013, 112:3029-3033.

29. Ferreira-da-Silva MF, Rodrigues RM, Andrade EF, Carvalho L, Groß U, Lüder CG, Barbosa HS: Spontaneous stage differentiation of mouse-virulent Toxoplasma gondii $\mathrm{RH}$ parasites in skeletal muscle cells: an ultrastructural evaluation. Mem Inst Oswaldo Cruz 2009, 140:196-200.

30. Ferreira-da-Silva MF, Takács AC, Barbosa HS, Gross U, Lüder CG: Primary skeletal muscle cells trigger spontaneous Toxoplasma gondii tachyzoite-to-bradyzoite conversion at higher rates than fibroblasts. Int J Med Microbiol 2009, 299:281-288.

31. Remington JS, Cavanaugh EN: Isolation of the encysted form of Toxoplasma gondii from human skeletal muscle and brain. N Engl J Med 1965, 273:1308-1310.

32. Tenter AM, Heckeroth AR, Weiss LM: Toxoplasma gondii: from animals to humans. Int J Parasitol 2000, 30:1217-1258.

33. Barbosa HS, Ferreira-Silva MF, Guimarães EV, Carvalho L, Rodrigues RM: Absence of vacuolar membrane involving Toxoplasma gondii during its intranuclear localization. J Parasitol 2005, 91:182-184.

34. Guimarães EV, Carvalho L, Barbosa HS: Primary culture of skeletal muscle cells as a model for studies of Toxoplasma gondii cystogenesis. J Parasitol 2008, 94:72-83.

35. Guimarães EV, Carvalho L, Barbosa HS: Interaction and cystogenesis of Toxoplasma gondii within skeletal muscle cells in vitro. Mem Inst Oswaldo Cruz 2009, 104:170-174.

36. Gomes AF, Guimarães EV, Carvalho L, Correa JR, Mendonça-Lima L, Barbosa HS: Toxoplasma gondii down modulates cadherin expression in skeletal muscle cells inhibiting myogenesis. BMC Microbio/ 2011, 11:110-111.

37. Coppens I: Contribution of host lipids to Toxoplasma pathogenesis. Cell Microbiol 2006, 8:1-9.

38. Caffaro CE, Boothroyd JC: Evidence for host cells as the major contributor of lipids in the intravacuolar network of Toxoplasma-infected cells. Eukaryot Cell 2011, 10:1095-1099.

39. Argemüller S, Fahimi HD: Imidazole-buffered osmium tetroxide: an excellent stain for visualization of lipids in transmission electron microscopy. Histochem J 1982, 14:823-835.

40. Locke M, Huie P: The mystery unstained Golgi complex cisternae. J Histochem Cytochem 1983, 31:1019-1032.

41. Gupta N, Zahn MM, Coppens I, Joiner KA, Voelker DR: Selective disruption of phosphatidylcholine metabolism of the intracellular parasite Toxoplasma gondii arrests its growth. J Biol Chem 2005, 280:16345-16353.

42. Liu X, Schnellmann RG: Calpain mediates progressive plasma membrane permeability and proteolysis of cytoskeleton-associated paxillin, talin and vinculin during renal cell death. J Pharmacol Exp Ther 2003, 304:63-70.
43. Dedieu S, Poussard S, Mazeres G, Grise F, Dargelos E, Cottin P, Brustis JJ: Myoblast migration is regulated by calpain through its involvement in cell attachment and cytoskeletal organization. Exp Cell Res 2004, 292:187-200.

44. Goldstein JL, Brown MS: Regulation of the mevalonate pathway. Nature 1990, 343:425-430.

45. Blader IJ, Manger ID, Boothroyd JC: Microarray analysis reveals previously unknown changes in Toxoplasma gondii-infected human cells. J Biol Chem 2001, 276:24223-24231.

46. Goldszmid SR, Coppens I, Lev A, Caspar P, Mellman I, Sher A: Host ERparasitophorous vacuole interaction provides a route of entry for antigen cross-presentation in Toxoplasma gondii-infected dendritic cells. J Exp Med 2009, 206:399-410.

47. Franzini-Armstrong C, Protasi F: Ryanodine receptors of striated muscles: a complex channel capable of multiple interactions. Physiol Rev 1997, 77:699-729.

48. Puzianowska-Kuznicka M, Kuznicki J: The SR and ageing II: calcium homeostasis. Ageing Res Rev 2009, 8:160-172.

49. Rossi D, Barone V, Giacomello E, Cusimano V, Sorrentino V: The sarcoplasmic reticulum: an organized patchwork of specialized domains. Traffic 2008, 9:1044-1049.

50. Sivaramakrishnan $\mathrm{V}$, Niranjali Devaraj S: Morin regulates the expression of INF-kappaB-p65 COX-2 and matrix metalloproteinases in diethylnitrosamine induced rat hepatocellular carcinoma. Chem Biol Interact 2009, 180:353-359.

51. Rangel Moreno J, Estrada Garcia I, De La Luz Garcia Hernandez M, Aguilar Leon D, Marquez R, Hernandez Pando R: The role of prostaglandin E2 in the immunopathogenesis of experimental pulmonary tuberculosis. Immunology 2002, 106:257-266.

52. Peng BW, Lin JY, Zhang T: Toxoplasma gondii induces prostaglandin E2 synthesis in macrophages via signal pathways for calcium-dependent arachidonic acid production and PKC-dependent induction of cyclooxygenase-2. Parasitol Res 2008, 102:1043-1050.

53. Renz H, Gong JH, Schmidt A, Nain M, Gemsa D: Release of tumor necrosis factor from macrophages: enhancement and suppression are dose-dependently regulated by prostaglandin E2 and cyclic nucleotides. J Immunol 1988, 141:2388-2393.

54. Betz M, Fox BS: Prostaglandin E2 inhibits production of Th1 lymphokines but not of Th2 lymphokines. J Immunol 1991, 146:108-113.

55. Skariah S, Mclntyre MK, Mordue DG: Toxoplasma gondii: determinants of tachyzoite to bradyzoite conversion. Parasitol Res 2010, 107:253-260.

56. Pedersen BK, Akerström TC, Nielsen AR, Fischer CP: Role of myokines in exercise and metabolism. J App/ Physiol 2007, 103:1093-1098.

57. Scharton-Kersten TM, Wynn TA, Denkers EY, Bala S, Grunvald E, Hieny S, Gazzinelli RT, Sher A: In the absence of endogenous IFN-gamma, mice develop unimpaired IL-12 responses to Toxoplasma gondii while failing to control acute infection. J Immunol 1996, 157:4045-4054.

58. Gazzinelli RT, Wysocka M, Hayashi S, Denkers EY, Hieny S, Caspar P, Trinchieri $G$, Sher A: Parasite-induced IL-12 stimulates early IFN-gamma synthesis and resistance during acute infection with Toxoplasma gondii. J Immunol 1994, 153:2533-2543.

59. Silva NM, Vieira JC, Carneiro CM, Tafuri WL: Toxoplasma gondii: the role of IFN-gamma, TNFRp55 and iNOS in inflammatory changes during infection. Exp Parasitol 2009, 123:65-72.

60. Lang C, Gross U, Lüder CG: Subversion of innate and adaptive immune responses by Toxoplasma gondii. Parasitol Res 2007, 100:191-203.

61. Nickdel MB, Roberts F, Brombacher F, Alexander J, Roberts CW: Counterprotective role for interleukin- 5 during acute Toxoplasma gondii infection. Infect Immun 2001, 69:1044-1052.

62. Matowicka-Karna J, Dymicka-Piekarska V, Kemona H: Does Toxoplasma gondii infection affect the levels of IgE and cytokines (IL-5, IL-6, IL-10, IL-12, and TNF-alpha)? Clin Dev Immunol 2009, 2009:374696.

doi:10.1186/1756-3305-7-47

Cite this article as: Gomes et al:: Toxoplasma gondii-skeletal muscle cells interaction increases lipid droplet biogenesis and positively modulates the production of IL-12, IFN-g and PGE 2 . Parasites \& Vectors 2014 7:47. 